The Northeast, the Punjab, and the Regionalization of Indian Politics

Author(s): Robert L. Hardgrave, Jr.

Source: Asian Survey, Vol. 23, No. 11 (Nov., 1983), pp. 1171-1181

Published by: University of California Press

Stable URL: http://www.jstor.org/stable/2644366

Accessed: 05-08-2015 16:09 UTC

Your use of the JSTOR archive indicates your acceptance of the Terms \& Conditions of Use, available at http://www.jstor.org/page/ info/about/policies/terms.jsp

JSTOR is a not-for-profit service that helps scholars, researchers, and students discover, use, and build upon a wide range of content in a trusted digital archive. We use information technology and tools to increase productivity and facilitate new forms of scholarship. For more information about JSTOR, please contact support@jstor.org. 


\section{THE NORTHEAST, THE PUNJAB, AND THE REGIONALIZATION OF INDIAN POLITICS}

\section{Robert L. Hardgrave, Jr.}

From the time of India's independence in 1947, cultural politics - whether in the demands for linguistic states, in the controversy over Hindi as the national language, or in the nativism of the "sons of the soil"- -have deepened regional identities. Episodic movements have been both the vehicle of politicization and its inevitable result. The government has typically met cultural demands with vacillation and indecision-sometimes by calculated neglect-only to be followed, in the face of prolonged agitation, by a combined response of force and accommodation.

Regionalism is rooted in India's cultural and linguistic diversity. Projected in geographic terms, it is at the state level both an ethnic and an economic phenomenon. It is an expression of heightened political consciousness, expanding participation, and increasing competition for scarce resources. Competition by the state is for Central financial allocation and Plan investment; for the individual, it involves access to education and jobs. Economic grievances-expressed in charges of unfairness, discrimination, or Center neglect - may be fused with cultural anxiety over language status and ethnic balance. It is this fusion that gives regionalism its potency. Language and culture, like religion, are at the core of an individual's identity and when politicized take a potentially virulent form.

So long as most states were under the Congress party umbrella, conflict between states and Center, among states, and within states could be accommodated within the framework of the party. Today, regionalism increasingly manifests itself through opposition to Congress in regional parties like the AIADMK and DMK in Tamil Nadu, the Akali Dal in the Punjab, and the

sity of Texas at Austin.

Robert L. Hardgrave, Jr., is Professor of Government at The Univer-

(C) 1983 by The Regents of the University of California. 
Telegu Desam in Andhra Pradesh, and in demands by opposition parties across the ideological spectrum for greater autonomy for the states.

The demand for greater state autonomy-increased financial resources, decentralization of planning, more independence in administrative areas for which states are constitutionally responsible-reflects, at least in part, an aspiration to bring government "closer to the people." The arguments are familiar in the American context, for federalism by its nature is "an invitation to struggle." That struggle in India, however, is aggravated by gross regional disparities, both in levels of development and in rates of growth, such that the gap between more advanced and backward regions continues to widen.

Disparities mean that the struggle between the states and the Center necessarily involves a struggle among states. All states do not share the same interests. More prosperous states, such as the Punjab, may resist redistribution of income among states by the Center, claiming that they are being unfairly exploited or that they do not receive a fair share back for what they contribute to the national economy. Other states, like Assam, Bengal, and Kerala, claim to be victims of Center neglect and discrimination. The more backward states, especially those of the Hindi heartland, look to the Center to redress disparities.

There are cross-cutting interests, and alliances among the states are likely to be ad hoc and temporary. Nevertheless, regionalism, as it expresses itself culturally and in the demand for greater state autonomy, is almost wholly a phenomenon of the non-Hindi speaking periphery, and it is this that continues to arouse fears of national disintegration. The North-South dichotomy has also been underscored by the Congress party losses in the 1983 Andhra and Karnataka state assembly elections. Indeed, Congress (I) General Secretary C. M. Stephen viewed the March 1983 meeting of the three opposition chief ministers from the South as "highly dangerous because it panders to the rising regionalist tendencies. The meeting," he said, "seems to have set the stage for a north-south fight."

The federal relationship involves a permanent tug-of-war, and "rising regionalist tendencies" are a predictable response to increasing centralization in both government and the Congress party under Indira Gandhi. Regionalism will likely impose increasing stress on the federal system as state movements seek to restore greater balance, but it does not pose a threat to the integrity of the Union. While we may be witnessing a regionalization of politics in India, there are countervailing forces of national integration. The development of a national system of transportation and communications 
and the growth and extension of a national market economy have increasingly bound India together.

The economy, both in its agricultural and industrial sectors, is becoming more national in character, drawing all regions into an interactive web of mutual dependency. Power and water supply systems serve interstate regions, and a national system of rail and road transport carries agricultural produce and industrial goods across the whole of India. Labor migration and employment opportunities for the middle class have given India's major cities ethnic diversity. An all-India managerial elite, in government services and in private business, draws expertise from every region. The emergence of a national system of communication - the reach of newspapers, radio, cinema, and (more limited) television-has nurtured the growth of national consciousness, the sense of being Indian, and it penetrates to all but the most isolated villages, linking the Center with the periphery, the rulers with the ruled, in (at least ideally) a two-way flow of information. But greater interdependence sharpens consciousness of regional disparities and intensifies the struggle among states to protect and advance their interests. Greater national integration, ironically, may deepen rather than alleviate stress on the federal system.

To say that India's national integrity is fundamentally secure is not to minimize the serious problems posed by disturbances in the Northeast and in the Punjab. These are strategically sensitive border areas, and prolonged agitation involves basic interests of national security. The government of India will do whatever it takes to bring these areas under control. In both Assam and the Punjab, the government initially pursued a policy of purposeful neglect ("constructive inaction") in hopes that the movements would burn themselves out. Instead, they have grown in intensity. More moderate agitation leaders are pressed by the extremists to harden their positions as options close and compromise becomes more difficult. Neither situation is beyond redemption, but how the government responds will have far-reaching implications for all of India.

In the tribal regions of the Northeast, the government has faced periodic armed insurrections from the time of independence. The creation of Nagaland in 1963 and the reorganization of the Northeast in 1972, with the formation of Mizoram, were welcomed by most tribals. On the whole, insurgency has been contained, but guerrilla activity by various underground organizations has not been brought wholly under control. Tribal regions of the Northeast remain under a form of quasi-martial law, reflecting both the 
continuing danger of unrest and the strategically vulnerable nature of the region. The Chinese no longer provide arms and training to tribal insurgents, but the adjoining region of northern Burma lies effectively outside the control of Rangoon and is both a source of arms into the Northeast and a haven for guerrillas.

In the late 1970s, clashes between the Indian Army and insurgents of the Mizo National Army grew in intensity, and the Mizo National Front, supporting independence for Mizoram, was outlawed in 1979. In Nagaland and Manipur, secessionist groups engage in periodic terrorist attacks against civil and military authorities. In 1982, for example, 20 soldiers were killed in an ambush in Manipur. The attack is believed to have been a combined operation by the People's Liberation Army (PLA) of Manipur and the National Socialist Council of Nagaland. The PLA also has ties with the new secessionist Tripur Sena in Tripura. All of these are tiny and with limited support. In 1980, underground elements in Assam, Manipur, Nagaland, Mizoram, Tripura, Meghalaya, and Arunachal Pradesh formed the Seven United Liberation Army (SULA). The organization calls for the creation of an independent federation of the Northeast by armed struggle. At this point, there is no reason to believe that SULA has coordinated the disparate tribal secessionist movements or affected a link between Assamese and tribal discontentmuch less that it has gained any substantial support in the Northeast. Nevertheless, the prospect of a united insurgency, however weak it may now be, is unsettling both militarily and politically and gives added urgency to settling the problems of the region.

The situation in the seven states and union territories of the Northeast is aggravated by the incursion of non-tribals onto tribal lands. Tribals-economically, culturally, and politically threatened-have responded in violence. The problem, which goes back well into the British period, has been exacerbated over the past decade as a result of immigration from Bangladesh and, to a lesser degree, from Nepal. In Tripura, the influx of Bengali refugees has shifted the ethnic balance and reduced tribals to a minority. Efforts to protect tribal lands and culture have not been successful, as the slaughter of 350 Bengalis in Tripura in June 1980 bears tragic witness. In Manipur and Meghalaya, student-led agitations against "foreigners"-Bengalis and Nepalese-have taken their lead from the movement in Assam.

The volatile situation in Assam is complicated by the unrest engendered by the occupation of tribal lands by both Assamese and Bengalis. Lalung tribals were responsible for the massacre of more than 1000 Bengali Muslims at Nellie during the February 1983 election violence. But tribal griev- 
ances are directed as much against the Assamese, as clashes between Boro tribals and Assamese villagers clearly reveal. The Plains Tribal Council of Assam, with the probable support of a majority of the tribals, calls for the creation of a separate tribal state of Udayachal to be carved out of Assam.

It is not tribal demands, however, but the "foreigner" issue that is the center of the political turmoil in Assam today. Immigration-primarily involving Bengalis from Bangladesh, most of whom are Muslim-has aroused Assamese fears that they will be reduced to a minority in their own state, if this has not, in fact, already taken place. The issue is political power. The conflict, rooted in the centuries-old love-hate relationship between Assamese and Bengalis, has been fueled in this century by Assamese apprehension that their language and culture are threatened. Bengalis have long dominated Assam state administration, but the extension of their control over the economy since independence has stimulated demands-primarily by Assamese youth-for the protection of jobs for "the sons of the soil." Economic concerns have been compounded by grievances that the Center has neglected the state, grievances expressed in the current agitation by such slogans as "Assam is not India's colony."

There is no way in this brief discussion, nor is it really necessary, to recapitulate the history of the Assam conflict. Suffice it to say that it was the discovery of "foreigners"-illegal aliens from Bangladesh-on the voter rolls in 1979 that was the catalyst for the movement that has engulfed Assam and confronted the Center with a seemingly intractable problem. Led by the All-Assam Students' Union and joined by other political organizations, including the All-Assam Gana Sangram Parishad, the agitation has mounted in intensity and has come to embrace in its support virtually the whole of the Assamese-speaking population. The leadership of the movement remains in the hands of the moderates, but the Sweecha Sevak Bahini, an extremist wing of the All-Assam Students' Union, proclaims violence against "foreigners" as the only solution to the Assam problem.

The conflict remains essentially ethnic, but it has taken an increasingly communal character as both Hindu and Muslim organizations have exploited mutual anxieties. Over the past three years' agitation, Islamic fundamentalist organizations, notably the Jamaat-e-Islami and the Tabligh Jamaat, have become increasingly active among Muslims, while the Hindu nationalist Rashtriya Swayamsevak Sangh (RSS), warning that Assam is being overrun by Muslim infiltrators, has dramatically expanded its activities in the state.

Center delay and Assamese intransigence have made a "solution" more difficult, and any settlement is likely to entail troublesome dilemmas. As- 
suming that a compromise can be reached for the cutoff date on the acceptance of immigrants to legal residence-sometime between 1961 as demanded by the Assamese and 1971 as accepted by the Center-the problems of detection, deportation, and dispersal remain.

Deportation would raise serious difficulties with Bangladesh. Moreover, the border itself is porous, and it would be as difficult to prevent the return of deportees as it has been to stem the flow of continued immigration, although the violence against Bengalis has probably slowed the movement across the border into Assam. Deportation-even it it were physically possible-would likely generate serious communal tension throughout India. "Foreigners" include both Hindus and Muslims, and the forceable return of Hindus (typically described as "refugees") to Bangladesh is widely viewed as unacceptable - and it would be politically explosive. On the other hand, deportation of Muslims alone would deepen insecurity among Indian Muslims generally, no doubt to the electoral cost of the Congress party, and it would surely draw sharp criticism and possible reprisal from the Muslim world.

Dispersal - that is, resettlement of immigrants outside Assam - has been held out both as an alternative to deportation and as a means to share the refugee burden. But the Constitution protects (with limited exceptions) the free movement of people, and it is unlikely that the immigrants would voluntarily uproot themselves for what would likely be an inhospitable reception elsewhere-although some are now doing so in fear for their lives.

As we look to the next few years, there will be enhanced efforts to prevent any further influx of foreigners and to return those who do get through. But deportation and dispersal of those already in India are likely to be limited at best. If a settlement between the Assamese and the Center can be reached, it is likely to emphasize protective legislation and Constitutional safeguards for Assamese linguistic, cultural, and political identity. It would include, as the first priority, the detection of "foreigners" and their removal from the voter rolls. The map of the Northeast might again be redrawn, possibly with the creation of an Udayachal tribal state, adjustments in the border with West Bengal, and cutting off the Bengali-speaking Cachar district from Assam to become a Union Territory. That Cachar might become a noncontiguous district of West Bengal is a less likely alternative so long as the Communist Party (Marxist) is in power in Bengal.

In a state of diminished size, an Assamese majority would be more easily assured, and cultural integrity could be buttressed by legislation making Assamese the medium of instruction in the schools and the sole language of 
state administration. Employment reservations and restrictions on the acquisition of property by foreigners would provide greater economic protection. An agreement between state and Center for a more favorable finance and Plan allocation for Assam-possibly involving a "royalty" to the state on petroleum production-would go a long way toward redressing past neglect. All of these raise potential constitutional questions and carry the danger of contagion - that is, that demands for similar protection would be raised in other states or regions.

The settlement of the Assam question is fraught with difficulties, though none are insurmountable. But what if a settlement cannot be reached and the situation continues to deteriorate? The Northeast already has the heaviest concentration of armed forces anywhere in India, and they are augmented by an array of paramilitary units. Given the strategic vulnerability of the Northeast and its importance to the Indian economy as a major source of domestic petroleum, the government, in all likelihood, would be prepared to invoke the emergency provisions of the Constitution and to impose martial law if required to maintain order. Although martial law has never been imposed to quell domestic unrest, disturbed tribal areas of the Northeast have been brought under quasi-military rule by the Armed Forces Act. Under the Act, in any area declared "disturbed," military officers are empowered to shoot to kill, to destroy buildings, to arrest without warrant, and to enter and search any premises without warrant. Barring the most extreme circumstances, this power is likely to be used most sparingly and only in those localities where civil authorities are unable to maintain order. But in the most extreme circumstances, the Northeast could become virtually an occupied territory.

The crisis in the Punjab is, like Assam, likely to be long term and farreaching in its implications. It involves a combination of economic, cultural, and religious issues, and at its core is the identity of the Sikh community. The current agitation led by the Akali Dal, the party of Sikh nationalism, is, in part, a continuation of the earlier movement for a Sikh-majority state of Punjabi Suba and for the protection of Sikh culture, religion, and the Punjabi language.

In 1966, the Center yielded to Sikh demands for a separate state, but the creation of the Punjab and Haryana left the question of Chandigarh, the capital, unresolved. The decision, taken in 1970, to award the city to the Punjab, with two northwestern Punjab tehsils (subdistricts) going to Haryana in exchange was never implemented. This has become one of the major issues of renewed agitation, though the Akalis want Chandigarh now and the matter of the tehsils transfer to be decided by an independent tribunal. 
Another major issue involves the allocation of river water for irrigation among the Punjab, Haryana, and Rajasthan. The Akalis demand a greater share to meet the vastly greater needs of the Punjab, India's granary. This too would be placed before an independent tribunal.

The Akali demands, embodied in the 1973 Anandpur resolution, include virtually complete autonomy for the state, leaving to the Center only defense, external affairs, communications, currency, and railways. This demand-short of the call for an independent Khalistan sought by the outlawed Dal Khalsa -is more a talking point on Center-state relations than a serious aspiration, at least at this stage. But while few Sikhs today want Khalistan, the line between regional aspirations and support for secession could be crossed as extremists gain greater power. Other Akali demands address various grievances and express a basic concern for the protection of Sikh culture and religious values.

Given the success of the Sikh community, their representation in the public services and in the military, and the wealth of the Punjab (with a per capita income more than twice that of the all-India average), there is little sympathy in India for Sikh claims of discrimination. In addition, much to the outrage of Akali extremists, most Hindus do not regard Sikhism as a separate religion, though they do hold the Sikhs in high esteem within the Hindu fold.

The Center has accepted the more symbolic religious demands, including the declaration of Amritsar as a "holy city" and the ban on the sale of cigarettes and liquor within the vicinity of the Golden Temple. It has also indicated a willingness to consider the establishment of tribunals to adjudicate the territorial and water issues, but not until the agitation itself is called off. (The Center, its representatives have stated, will not negotiate with a loaded gun pointed at its head.) And in April 1983, against the backdrop of rising regionalism but with the situation in the Punjab at the forefront of consideration, the government established a commission under retired Supreme Court Justice R. S. Sarkaria to review Center-state relations more broadly.

The problem in the Punjab, as in Assam, is political power, and it is partly a question of ethnic balance. The Sikhs constitute some $52 \%$ of the population in the Punjab, and the balance is shifting against them as a result of their own success as a community. Entrepreneurial spirit has led to an out-migration of Sikhs (there are more Sikhs in India outside the Punjab than within), while agricultural prosperity in the Punjab has drawn Hindu laborers into the state, some from as far as Bihar. 
The political problem of the Punjab involves the exclusion of the Akalis from power. Indeed, when the Akalis were in power during the period of Janata rule at the Center, they did not press their demands. The Akalis had struggled for Punjabi Suba, but when their goal was attained, they found themselves excluded from power except for brief interludes of coalition government. The Akalis themselves were factionally divided and engaged in continuous internecine struggle, but the Sikhs, divided by sect and by caste, were not wholly behind the Akali Dal. Non-Jat Sikhs joined with Hindus in support of the Congress, and given the ethnic balance in the state, the effect was to exclude the majority of Sikhs, represented by the Akali Dal, from power. A succession of Sikh Congress chief ministers ruled the state, but without the confidence of the larger number of their own community. Political stability in the Punjab requires Akali participation in governmenton their own if they can make it or in coalition either with the Congress or the opposition. The only times that the Akali Dal has headed a government has been with the coalition support of the former Jana Sangh and the Janata party. The Bharata Janata Party (BJP) — even with its aura of Hindu nationalism-remains a potential ally, but the Sikh-Hindu communal distrust engendered by the current unrest may force the Akalis into political isolation. A settlement of the Punjab crisis and the prospect of shared power with the Congress could split the Akalis, driving a wedge between the moderates and the extremists. The Congress in the Punjab is divided, however, and its contending factions have played to various Sikh groups, including extremists who have thereby gained increased leverage within the community. The agitation, while exposing the division among the Sikhs, has strengthened Sikh revivalism, heightened political consciousness, and broadened the base of Akali support, especially among youth.

There is a basis for compromise in the Punjab, but the Center's delay, insensitivity, and ineptitude have strengthened the hands of the Sikh extremists. And therein lies the problem, not just for the resolution of the current crisis, but for the future. The Sikh extremists are unlikely to be party to any settlement and may well raise the ante as the Center meets Akali demands. The key figure in the current agitation is Sant Jarnail Singh Bhrindranwale, a zealot, and it is unrest that has been his vehicle to power. Sikh revivalism has been stoked by his portrayal of the "Sikh nation" in danger, and there is widespread fear among Sikhs of merging back into Hinduism and of losing their separate identity. Sikh fundamentalism has been met by heightened Hindu consciousness, and militant Hindus have organized the Punjab Hindu Surakshu Samiti (League for Hindu Protection). Sikh-Hindu relations in the 
Punjab have rarely been worse or more volatile than they are today. A relatively minor incident (much less an act of desecration such as occurred in 1982 when the decapitated head of a bullock was placed before a Hindu temple, an act as offensive to Sikhs as to Hindus) could provoke widespread communal violence that could spill over into neighboring Haryana and to Delhi. Sikh-Hindu rioting in Patiala in May 1983 began as a bazaar dispute over noise from a loudspeaker. It ended with police firings and the army on the alert to move in.

Violence in the Punjab - whether it be communal or an Akali "holy war" for satisfaction of their demands-raises an ominous prospect. Punjabis, Sikhs and Hindus alike, have a well-earned reputation as a "martial race," and unrest will not be easily controlled. The capacity of the police or even paramilitary forces to control serious violence is limited, and the use of the army, given Sikh representation in the armed forces, would be a matter of great sensitivity. ${ }^{1}$

Any settlement in the Punjab must involve a substantive, not just symbolic, response to Akali demands if moderate leaders are to retain their credibility among Sikhs and if unrest is to be effectively controlled. But violence in the Punjab is unlikely to be wholly contained. On the defensive, Sikh extremists could continue to use terrorism to maintain visibility as a political force in the Punjab and as a means of drawing support from among the most disaffected elements of the Sikh community.

No settlement will come without costs. While Prime Minister Gandhi would surely win kudos for reaching a solution to the problem, it could mean serious political costs to Congress in Haryana and Rajasthan-with implications for continued Congress control at the Center-and could even precipitate violent reaction. For the states involved, the territorial and water issues are critical, especially the latter. Negotiations for a Punjab settlement must involve the affected states, and the settlement must be broadly accepted as fair if unrest is not to spread to other states.

The implications of the Center response, whatever they may be, to Akali and Assamese demands will be far-reaching. Center delay in each case has made settlement both more difficult and more costly, yet failure to reach settlements soon will only deepen discontent in Assam and the Punjab and require ever greater applications of repressive force, surely a tragic consequence for the Indian democratic body politic. On the other hand, yielding to demands under pressure gives an efficacy to violence that carries the danger of contagion. Success in demands for protective legislation for language and culture and for greater state autonomy for Assam and the Punjab 
is likely to give impetus and strength to regional movements throughout India. This should not, as some fear, bring on the disintegration of the nation. But pressure for greater administrative and political decentralization will surely impose stress on relations between the states and the Center and among the states themselves as India seeks to redress the "distortions" of centralization and to achieve new balance in the federal system.

\section{Notes}

1. There is no evidence of support for Akali demands among the Sikh military, though there must surely be an element of sympathy. The Akali appeal to retired officers to rally to the cause drew little response.

Among Sikh grievances is the belief that they are now subject to discrimination in armed forces recruitment. In order to make the military more generally representative of the population, a 1980 government order provides that recruitment be conducted proportionate to population by state rather than strictly by merit. The Akalis allege that the Sikhs, now numbering some $15 \%$ of the armed forces, will be the principal victims if the rule is applied. 